\title{
A hybrid egalitarian bargaining game-DEA and sustainable network design approach for evaluating, selecting and scheduling urban road construction projects
}

\author{
Reza Mahmoudi \\ Department of Industrial and Systems Engineering \\ Isfahan University of Technology \\ 84156-83111 Isfahan, Iran \\ E-mail: $\underline{\text { r.mahmoudi@in.iut.ac.ir }}$ \\ Seyyed-Nader Shetab-Boushehri \\ Department of Industrial and Systems Engineering \\ Isfahan University of Technology \\ 84156-83111 Isfahan, Iran \\ E-mail: $\underline{\text { shetab@cc.iut.ac.ir }}$ \\ Seyed Reza Hejazi \\ Department of Industrial and Systems Engineering \\ Isfahan University of Technology \\ 84156-83111 Isfahan, Iran \\ E-mail: rehejazi@cc.iut.ac.ir \\ Ali Emrouznejad* \\ Aston Business School \\ Aston University \\ Birmingham, B47ET, UK \\ E-mail: a.emrouznejad@aston.ac.uk \\ Parisa Rajabi \\ Department of Industrial and Systems Engineering \\ Isfahan University of Technology \\ 84156-83111 Isfahan, Iran \\ E-mail: parisarajabi1993@gmail.com
}

Corresponding author at: Aston Business School, Aston University, Birmingham, UK.

E-mail address: a.emrouznejad@aston.ac.uk (A. Emrouznejad).

URL: http://www.Emrouznejad.com (A. Emrouznejad) 


\title{
A hybrid egalitarian bargaining game-DEA and sustainable network design approach for evaluating, selecting and scheduling urban road construction projects
}

\begin{abstract}
Selecting and scheduling urban road construction projects (URCPs) is inherently an Urban Network Design Problem (UNDP) with a complex decision making process. Recently some studies have focused on sustainable UNDP, using different mathematical methods. In this paper, first a new network data envelopment analysis (NDEA) model has been developed. Then, considering sustainability dimensions, by integrating data envelopment analysis (DEA), game theory and sustainable UNDP, a bi-level model has been proposed for selecting and scheduling URCPs. A meta-heuristic algorithm is proposed to solve the presented bi-level model. Different test instances are solved to show the acceptable performance of proposed algorithm in both solution quality and execution time. Afterwards, the proposed model is applied to study the problem of urban road construction projects selection in a real-world case study of urban transportation network of Isfahan city in Iran. The results show that by applying obtained solution the environmental and social performance of the network has been improved and the performance of the network is almost efficient in all evaluation periods.
\end{abstract}

Keywords: Network data envelopment analysis; Egalitarian bargaining game; Transportation; Sustainable network design problem; Urban road project selection; Scheduling. 


\section{References}

Adenso-Díaz, B., Lozano, S., Moreno, P., 2016. How the environmental impact affects the design of logistics networks based on cost minimization. Transportation Research Part D: Transport and Environment 48, 214-224.

Akyol, D.E., De Koster, R.B., 2018. Determining time windows in urban freight transport: A city cooperative approach. Transportation Research Part E: Logistics and Transportation Review 118, 34-50.

Alexopoulos, A., Assimacopoulos, D., Mitsoulis, E., 1993. Model for traffic emissions estimation. Atmospheric Environment. Part B. Urban Atmosphere 27, 435-446.

Alfiero, S., Cantino, V., Capecci, G., Esposito, A., 2019. The Italian Bus Transportation Sector: The Management of Environmental Risks as a Factor for Achieving a Business Sustainability, The Future of Risk Management, Volume I. Springer, pp. 3-26.

Amirgholy, M., Shahabi, M., Gao, H.O., 2017. Optimal design of sustainable transit systems in congested urban networks: A macroscopic approach. Transportation Research Part E: Logistics and Transportation Review 103, 261-285.

Amirteimoori, A., Kordrostami, S., Azizi, H., 2016. Additive models for network data envelopment analysis in the presence of shared resources. Transportation Research Part D: Transport and Environment 48, 411424.

Barron, E.N., 2013. Game theory: an introduction. John Wiley \& Sons.

Barua, B., 2013. Provincial healthcare index 2013.

Bazaraa, M.S., Jarvis, J.J., Sherali, H.D., 2011. Linear programming and network flows. John Wiley \& Sons.

Bazaraa, M.S., Sherali, H.D., Shetty, C.M., 2013. Nonlinear programming: theory and algorithms. John Wiley \& Sons.

Ben-Ayed, O., Blair, C.E., 1990. Computational difficulties of bilevel linear programming. Operations Research 38, 556-560.

Binmore, K., Rubinstein, A., Wolinsky, A., 1986. The Nash bargaining solution in economic modelling. The RAND Journal of Economics, 176-188.

Braess, D., Nagurney, A., Wakolbinger, T., 2005. On a paradox of traffic planning. Transportation science 39, 446-450.

Camporeale, R., Caggiani, L., Fonzone, A., Ottomanelli, M., 2017. Quantifying the impacts of horizontal and vertical equity in transit route planning. Transportation Planning and Technology 40, 28-44.

Cantarella, G.E., Vitetta, A., 2006. The multi-criteria road network design problem in an urban area. Transportation 33, 567-588.

Charnes, A., Cooper, W.W., Rhodes, E., 1978. Measuring the efficiency of decision making units. European journal of operational research 2, 429-444.

Chen, A., Yang, C., 2004. Stochastic transportation network design problem with spatial equity constraint. Transportation Research Record: Journal of the Transportation Research Board, 97-104.

Davis, C., 2011. Water Utility Benchmarking: Measurement, Methodologies, and Performance Incentives by Sandford V. Berg, 2010, paperback, 172 pages, IWA Publishing, London. ISBN: 1843392720. IWA Publishing.

Dobos, I., Vörösmarty, G., 2019. Inventory-related costs in green supplier selection problems with Data Envelopment Analysis (DEA). International Journal of Production Economics 209, 374-380.

Egilmez, G., McAvoy, D., 2013. Benchmarking road safety of US states: A DEA-based Malmquist productivity index approach. Accident Analysis \& Prevention 53, 55-64.

Eltoukhy, A.E., Wang, Z., Chan, F.T., Fu, X., 2019. Data analytics in managing aircraft routing and maintenance staffing with price competition by a Stackelberg-Nash game model. Transportation Research Part E: Logistics and Transportation Review 122, 143-168.

EMME, 2017. The world's most trusted transportation planning software. https://www.inrosoftware.com/index.php/en/products/emme/.

Emrouznejad, A., Yang, G.-1., 2018. A survey and analysis of the first 40 years of scholarly literature in DEA: 1978-2016. Socio-Economic Planning Sciences 61, 4-8. 
Farahani, R.Z., Miandoabchi, E., Szeto, W.Y., Rashidi, H., 2013. A review of urban transportation network design problems. European Journal of Operational Research 229, 281-302.

Ghaderi, A., Jabalameli, M.S., 2013. Modeling the budget-constrained dynamic uncapacitated facility location-network design problem and solving it via two efficient heuristics: A case study of health care. Mathematical and Computer Modelling 57, 382-400.

Hosseininasab, S.-M., Shetab-Boushehri, S.-N., 2015. Integration of selecting and scheduling urban road construction projects as a time-dependent discrete network design problem. European Journal of Operational Research 246, 762-771.

Hosseininasab, S.-M., Shetab-Boushehri, S.-N., Hejazi, S.R., Karimi, H., 2018. A multi-objective integrated model for selecting, scheduling, and budgeting road construction projects. European Journal of Operational Research.

Kalai, E., 1977. Proportional solutions to bargaining situations: interpersonal utility comparisons. Econometrica: Journal of the Econometric Society, 1623-1630.

Kim, B.J., Kim, W., Song, B.H., 2008. Sequencing and scheduling highway network expansion using a discrete network design model. The Annals of Regional Science 42, 621-642.

Laporte, G., Mesa, J.A., Perea, F., 2010. A game theoretic framework for the robust railway transit network design problem. Transportation Research Part B: Methodological 44, 447-459.

Leblanc, L.J., 1975. An algorithm for the discrete network design problem. Transportation Science 9, 183-199.

Lee, C.-Y., Wang, K., Sun, W., 2019. Allocation of Emissions Permit for China's Iron and Steel Industry in an Imperfectly Competitive Market: A Nash Equilibrium DEA Method. IEEE Transactions on Engineering Management.

Liu, J., Zhu, J., Zhang, J., 2018. A DEA-based approach for competitive environment analysis in global operations strategies. International Journal of Production Economics 203, 110-123.

Mahmoudi, R., Emrouznejad, A., Khosroshahi, H., Khashei, M., Rajabi, P., 2019a. Performance evaluation of thermal power plants considering CO2 emission: A multistage PCA, Clustering, Game theory and Data Envelopment Analysis. Journal of Cleaner Production 223, 641-650.

Mahmoudi, R., Emrouznejad, A., Rasti-Barzoki, M., 2019b. A bargaining game model for performance assessment in network DEA considering sub-networks: a real case study in banking. Neural Computing and Applications, 1-19.

Mahmoudi, R., Emrouznejad, A., Shetab-Boushehri, S.-N., Hejazi, S.R., 2019c. The origins, development and future directions of Data Envelopment Analysis approach in transportation systems. Socio-Economic Planning Sciences.

Mahmoudi, R., Shetab, N., Hejazi, R., Emrouznejad, A., 2019d. Determining the relative importance of sustainability evaluation criteria of urban transportation network. sustainable cities and society.

Miandoabchi, E., Daneshzand, F., Farahani, R.Z., Szeto, W.Y., 2015. Time-dependent discrete road network design with both tactical and strategic decisions. Journal of the Operational Research Society 66, 894-913.

Miandoabchi, E., Daneshzand, F., Szeto, W.Y., Farahani, R.Z., 2013. Multi-objective discrete urban road network design. Computers \& Operations Research 40, 2429-2449.

Miandoabchi, E., Farahani, R.Z., 2011. Optimizing reserve capacity of urban road networks in a discrete network design problem. Advances in Engineering Software 42, 1041-1050.

Miandoabchi, E., Farahani, R.Z., Szeto, W.Y., 2012. Bi-objective bimodal urban road network design using hybrid metaheuristics. Central European Journal of Operations Research 20, 583-621.

Nash, J., Shapley, L., 1950. A simple three-person poker game. Essays on Game Theory.

Osborne, M.J., Rubinstein, A., 1994. A course in game theory. MIT press.

Özkır, V., Demirel, T., 2012. A fuzzy assessment framework to select among transportation investment projects in Turkey. Expert Systems with Applications 39, 74-80.

Petridis, K., Dey, P.K., Emrouznejad, A., 2017. A branch and efficiency algorithm for the optimal design of supply chain networks. Annals of Operations Research 253, 545-571.

Phadke, M.S., 1995. Quality engineering using robust design. Prentice Hall PTR.

Poorzahedy, H., Rouhani, O.M., 2007. Hybrid meta-heuristic algorithms for solving network design problem. European Journal of Operational Research 182, 578-596. 
Pternea, M., Kepaptsoglou, K., Karlaftis, M.G., 2015. Sustainable urban transit network design. Transportation Research Part A: Policy and Practice 77, 276-291.

Qin, J., Ni, L.-1., Shi, F., 2013. Mixed transportation network design under a sustainable development perspective. The Scientific World Journal 2013.

Qiu, X., Lee, C.-Y., 2019. Quantity discount pricing for rail transport in a dry port system. Transportation Research Part E: Logistics and Transportation Review 122, 563-580.

Qu, Y., Bektaş, T., Bennell, J., 2016. Sustainability SI: multimode multicommodity network design model for intermodal freight transportation with transfer and emission costs. Networks and Spatial Economics 16, 303-329.

Saeedi, H., Behdani, B., Wiegmans, B., Zuidwijk, R., 2019. Assessing the technical efficiency of intermodal freight transport chains using a modified network DEA approach. Transportation Research Part E: Logistics and Transportation Review 126, 66-86.

Seiford, L.M., Zhu, J., 2002. Modeling undesirable factors in efficiency evaluation. European journal of operational research 142, 16-20.

Sheffi, Y., 1985. Urban transportation networks. Prentice-Hall, Englewood Cliffs, NJ.

Sniedovich, M., 2008. Wald's maximin model: a treasure in disguise! The Journal of Risk Finance 9, 287-291.

Szeto, W., Jiang, Y., Wang, D., Sumalee, A., 2015. A sustainable road network design problem with land use transportation interaction over time. Networks and Spatial Economics 15, 791-822.

Tavana, M., Khalili-Damghani, K., Santos Arteaga, F.J., Mahmoudi, R., Hafezalkotob, A., 2018. Efficiency decomposition and measurement in two-stage fuzzy DEA models using a bargaining game approach. Computers \& Industrial Engineering 118, 394-408.

Thomopoulos, N., Grant-Muller, S., Tight, M., 2009. Incorporating equity considerations in transport infrastructure evaluation: Current practice and a proposed methodology. Evaluation and program planning 32, 351-359.

Tsao, Y.-C., Thanh, V.-V., 2019. A multi-objective mixed robust possibilistic flexible programming approach for sustainable seaport-dry port network design under an uncertain environment. Transportation Research Part E: Logistics and Transportation Review 124, 13-39.

Tzeng, G.H., Teng, J.Y., 1993. Transportation investment project selection with fuzzy multiobjectives. Transportation Planning and Technology 17, 91-112.

Wald, A., 1950. Basic ideas of a general theory of statistical decision rules. Selected papers in Statistics and Probability, 656-668.

Wang, H., Lam, W.H., Zhang, X., Shao, H., 2015. Sustainable transportation network design with stochastic demands and chance constraints. International Journal of Sustainable Transportation 9, 126-144.

Wei, R., Liu, X., Mu, Y., Wang, L., Golub, A., Farber, S., 2017. Evaluating public transit services for operational efficiency and access equity. Journal of Transport Geography 65, 70-79.

Weng, K., Qu, B., 2009. The optimization of road building schedule based on budget restriction. Kybernetes $38,441-447$.

Yang, H., Wang, J., 2002. Travel time minimization versus reserve capacity maximization in the network design problem. Transportation Research Record: Journal of the Transportation Research Board, 17-26.

Yin, Y., Lawphongpanich, S., 2006. Internalizing emission externality on road networks. Transportation Research Part D: Transport and Environment 11, 292-301.

Zhang, L., Yang, H., Wu, D., Wang, D., 2014. Solving a discrete multimodal transportation network design problem. Transportation Research Part C: Emerging Technologies 49, 73-86.

Zheng, N., Geroliminis, N., 2016. Modeling and optimization of multimodal urban networks with limited parking and dynamic pricing. Transportation Research Part B: Methodological 83, 36-58.

Ziyou, G., Yifan, S., 2002. A reserve capacity model of optimal signal control with user-equilibrium route choice. Transportation Research Part B: Methodological 36, 313-323. 